\title{
Enhanced electrochemical performance of high voltage spinel cathode by using fluoroethylene carbonate as an electrolyte additive
}

\author{
Jiahui Chen ${ }^{1, a}$, Hui Zhang ${ }^{1, b}$ and Cuihua $\mathrm{Li}^{1, \mathrm{c}^{*}}$ \\ ${ }^{1}$ Department of Chemistry and Chemical Engineering, Shenzhen University, Shenzhen, China \\ aalivecjh@163.com, ${ }^{b}$ zhanghui2009love@126.com, ${ }^{c}$ licuihuasz@163.com
}

Keywords: Lithium ion battery, electrolyte additive, fluoroethylene carbonate, spinel cathode.

Abstract. Spinel $\mathrm{LiNi}_{0.5} \mathrm{Mn}_{1.5} \mathrm{O}_{4}$ cathode has attracted considerable attention because of its high energy density and operating potential. However, current carbonate electrolytes cannot meet the demand of this high voltage cathode. Here, we demonstrate that fluoroethylene carbonate (FEC) substantially improve the electrochemical performance of $\mathrm{LiNi}_{0.5} \mathrm{Mn}_{1.5} \mathrm{O}_{4}$ cathode. In presence of 2 wt \% FEC, $\mathrm{Li} / \mathrm{LiNi}_{0.5} \mathrm{Mn}_{1.5} \mathrm{O}_{4}$ cell exhibits an improved discharge capacity retention of $90.3 \%$ after 200 cycles at room temperature. When cycled at $55{ }^{\circ} \mathrm{C}$, the cell with FEC achieves discharge capacity retention of $92.8 \%$ after 100 cycles comparing of $72.7 \%$ of the cell without FEC. Our investigation reveals that FEC alleviates the electrolyte decomposition under high voltage and temperature conditions and forms a less resistive film on the cathode surface.

\section{Introduction}

The development of electric vehicles and energy storage systems requires the exploitation of advance lithium ion batteries with higher energy density [1,2]. One effective way to enhance the energy density of the lithium battery is to increase its working potential. Spinel $\mathrm{LiNi}_{0.5} \mathrm{Mn}_{1.5} \mathrm{O}_{4}$ has attracted extensive interests due to its high operating potential $\left(\sim 4.7 \mathrm{~V} \mathrm{vs.} \mathrm{Li}^{\prime} / \mathrm{Li}^{+}\right)$and energy density $\left(650 \mathrm{~W} \mathrm{~h} \mathrm{~kg}^{-1}\right)$ [3]. A major challenge for the practical application of this high voltage cathode is the instability of currently used carbonated-based electrolyte beyond 4.5 V [4]. Moreover, the interfacial side reaction between cathode and electrolyte becomes more pronounced at elevated temperature. This side reaction readily causes rapid capacity fade and low coulombic efficiency.

To improve the electrolyte stability, many additives has been explored with focus on protecting the high voltage cathode surface. Among them, fluoroethylene carbonate (FEC) has been considered as an electrolyte additive to form a stable solid/electrolyte interphase (SEI) film for many anodes, such as, graphite [5] and silicon [6]. However, the effect of FEC on the cathode performance has been less investigated. Ryou et al [7] demonstrated that addition of FEC improve the capacity retention of $\mathrm{LiMn}_{2} \mathrm{O}_{4} /$ graphite cell at $60{ }^{\circ} \mathrm{C}$. This positive effect is originated from the SEI film formed on the graphite surface. Park et al [8] reported that incorporation of FEC into $\mathrm{Li} / \mathrm{LiCoO}_{2}$ cell helps to increase the polycarbonate content in the SEI film, which enhances the ion conductivity of SEI film and improves electrochemical performance. Li et al [9] reported that FEC can improve the compatibility between lithium-rich cathode and electrolyte via forming a stabilized SEI film.

In the present study, we expected that FEC is able to improve the electrolyte stability and capacity retention of $\mathrm{LiNi}_{0.5} \mathrm{Mn}_{1.5} \mathrm{O}_{4}$ cathode especially at high temperature. Electrochemical measurements, including cycling test, electrochemical impedance spectroscopy and chronoamperometry, were carried out to investigate the effect of FEC on $\mathrm{Li} / \mathrm{LiNi}_{0.5} \mathrm{Mn}_{1.5} \mathrm{O}_{4}$ cell.

\section{Experimental}

The blank electrolyte was composed of $1 \mathrm{MLiPF}_{6}$ in a solvent mixture of ethylene carbonate (EC), ethyl methyl carbonate (EMC), and diethyl carbonate (DEC) in 3:5:2 volume ratio. The additive containing electrolyte was obtained by adding $2 \mathrm{wt} \%$ FEC (J\&K Chemical) into the blank electrolyte. The cathode active material $\mathrm{LiNi}_{0.5} \mathrm{Mn}_{1.5} \mathrm{O}_{4}$ (Shenzhen Tianjiao) was mixed with acetylene carbon black and polyvinylidene fluoride binder at a weight ratio of $8: 1: 1$ in $\mathrm{N}$-methyl pyrrolidone to create 
slurry. The resulting slurry was cast onto an aluminum foil and dried overnight at $70{ }^{\circ} \mathrm{C}$. After drying, the coated foil was punched into round discs and dried again at $110{ }^{\circ} \mathrm{C}$ for $8 \mathrm{~h}$. CR2032 type coin cell with $\mathrm{LiNi}_{0.5} \mathrm{Mn}_{1.5} \mathrm{O}_{4}$ cathode, lithium foil anode, and Celgard 2400 separator was assembled in an Mbraun Ar-filled glove box. Same amount of electrolyte of $50 \mu \mathrm{L}$ was added for each coin cell.

Galvanostatic charge/discharge cycles of $\mathrm{Li} / \mathrm{LiNi}_{0.5} \mathrm{Mn}_{1.5} \mathrm{O}_{4}$ cells were carried out between 3.5 and 5.0 V on a CT2001A battery test system (Wuhan Land Electronics Co. Ltd, China). Thereafter, the cells were cycled with a constant rate of $0.1 \mathrm{C}\left(1 \mathrm{C}=147 \mathrm{mAh} \mathrm{g}^{-1}\right)$ at room temperature $\left(\mathrm{ca} .25^{\circ} \mathrm{C}\right)$ for five formation cycles and then with $0.5 \mathrm{C}$ at room and elevated temperature. Electrochemical impedance spectroscopy (EIS) was conducted on the Solartron 1470E cell test system in frequency range of $10^{5} \mathrm{~Hz}$ to $0.01 \mathrm{~Hz}$ with the ac perturbation amplitude of $10 \mathrm{mV}$. Chronoamperometry was performed on the Solartron $1470 \mathrm{E}$ cell test system as well. The $\mathrm{Li} / \mathrm{LiNi}{ }_{0.5} \mathrm{Mn}_{1.5} \mathrm{O}_{4}$ cells with and without FEC were charged to 5.2 and $5.5 \mathrm{~V}$ respectively at $0.1 \mathrm{C}$, followed by constant potential holding at 5.2 and $5.5 \mathrm{~V}$ for $24 \mathrm{~h}$.

\section{Results and discussion}

The cycling performance of $\mathrm{Li} / \mathrm{LiNi}_{0.5} \mathrm{Mn}_{1.5} \mathrm{O}_{4}$ cells with and without $\mathrm{FEC}$ is given in Fig. 1 . The cell cycled in blank electrolyte delivers a discharge capacity of $132.1 \mathrm{mAh} \mathrm{g}^{-1}$ at the first cycle and decrease to $109.3 \mathrm{mAh} \mathrm{g}^{-1}$ after 200 cycles, so that relatively low capacity retention of $82.7 \%$ is achieved. For the cell cycled in FEC containing electrolyte, reversible discharge capacity of $121.8 \mathrm{mAh} \mathrm{g}^{-1}$ can be obtained at the 200th cycle, corresponding to capacity retention of $90.3 \%$. In addition, the coulombic efficiency of the cell with FEC quickly rises to $98.6 \%$ after five formation cycles and remains stable around $99 \%$ for the subsequent cycles. This higher coulombic efficiency implies that electrolyte decomposition is mitigated by the addition of FEC. It is interesting to find that the cell with FEC shows lower initial coulombic efficiency than that without FEC, which is probably due to the additive involved SEI film formation on the $\mathrm{LiNi}_{0.5} \mathrm{Mn}_{1.5} \mathrm{O}_{4}$ cathode surface.

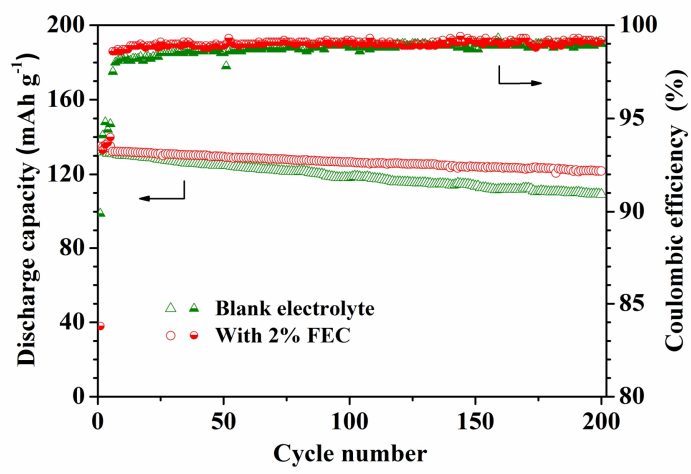

Fig. 1 Cycling performance of $\mathrm{Li} / \mathrm{LiNi} i_{0.5} \mathrm{Mn}_{1.5} \mathrm{O}_{4}$ cells with and without $\mathrm{FEC}$ at room temperature.

More clear evidence for this improved cycling performance bought by FEC is presented in Fig. 2. Electrochemical impedance spectra of $\mathrm{Li} / \mathrm{LiNi}_{0.5} \mathrm{Mn}_{1.5} \mathrm{O}_{4}$ cells with and without FEC were collected before cycle and after 200 cycles, respectively. Generally, the high frequency semicircle is corresponded to the surface film resistance $\left(R_{f}\right)$, and the middle frequency semicircle is related to the charge transfer resistance $\left(\mathrm{R}_{\mathrm{ct}}\right)$ between electrode and electrolyte. The low frequency straight line is associated with the $\mathrm{Li}^{+}$diffusion process in the electrode. Before cycling, the impedance of the cell with FEC is much smaller. This is most likely due to the fact that FEC is more easily enrich the $\mathrm{LiNi}_{0.5} \mathrm{Mn}_{1.5} \mathrm{O}_{4}$ cathode and consequently resulting in low impedance [9]. After 200 cycles, the cell cycled in blank electrolyte shows larger $\mathrm{R}_{\mathrm{f}}$ than the one cycled in FEC containing electrolyte. This can be explained by the continuous accumulation of the undesired decomposition products of electrolyte onto the cathode surface. In contrary, FEC is able to alleviate the electrolyte decomposition by forming protective SEI film, and resulting in the decrease of $\mathrm{R}_{\mathrm{f}}$. Moreover, the cell with FEC exhibits smaller 
$\mathrm{R}_{\mathrm{ct} .}$ indicating that FEC derived SEI film is beneficial for facilitating charge transfer. Therefore, the improved cycling performance with FEC is believed to be due to the high quality SEI film formation.
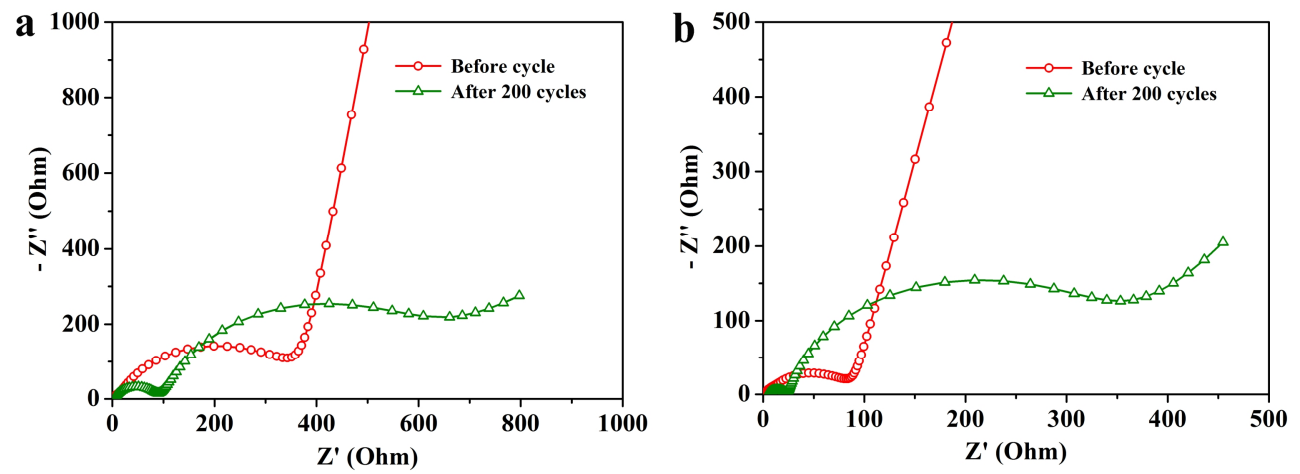

Fig. 2 Electrochemical impedance spectra of $\mathrm{Li} / \mathrm{LiNi}_{0.5} \mathrm{Mn}_{1.5} \mathrm{O}_{4}$ cells (a) without and (b) with FEC.

To verify the anodic stability of FEC containing electrolyte, the leakage current of $\mathrm{Li} / \mathrm{LiNi}{ }_{0.5} \mathrm{Mn}_{1.5} \mathrm{O}_{4}$ cells was monitored at constant charging voltages of 5.2 and $5.5 \mathrm{~V}$ for $24 \mathrm{~h}$. As shown in Fig. 3, the cell with blank electrolyte shows larger leakage current at both $5.2 \mathrm{~V}$ and $5.5 \mathrm{~V}$, suggesting that severe decomposition of the blank electrolyte. However, incorporation of FEC reduces the leakage current, especially at $5.5 \mathrm{~V}$. It is thought that the $\mathrm{SEI}$ film formed on $\mathrm{LiNi}_{0.5} \mathrm{Mn}_{1.5} \mathrm{O}_{4}$ cathode surface in the FEC containing electrolyte is much more stable and thus helps the electrolyte tolerate high voltages.

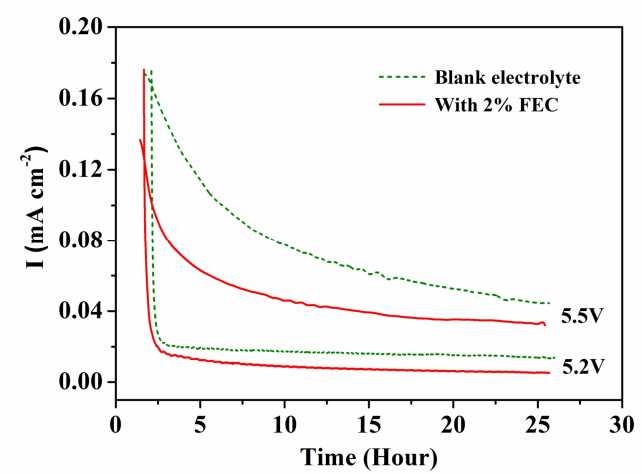

Fig. 3 Potentiostatic profiles of $\mathrm{Li} / \mathrm{LiNi}{ }_{0.5} \mathrm{Mn}_{1.5} \mathrm{O}_{4}$ cells with and without $\mathrm{FEC}$ maintained at charging voltage of 5.2 and $5.5 \mathrm{~V}$ respectively.

Fig. 4a presents the cycling performance of $\mathrm{Li} / \mathrm{LiNi}_{0.5} \mathrm{Mn}_{1.5} \mathrm{O}_{4}$ cells at $55{ }^{\circ} \mathrm{C}$. The cell with FEC exhibits dramatically improved discharge capacity. It delivers a discharge capacity of $118.4 \mathrm{mAh} \mathrm{g}^{-1}$ after 100 cycles and shows capacity retention of $92.8 \%$. While for the cell without FEC suffers from severe capacity fading, resulting a low discharge capacity of $91.6 \mathrm{mAh} \mathrm{g}^{-1}$ and with capacity retention of $72.7 \%$ after 100 cycles. The substantially improved cycling performance demonstrates that the harmful interfacial side reaction between cathode and electrolyte is alleviated due to the effective protection of SEI film formed by FEC. Unfortunately, without the addition of FEC, unfavorable SEI film generated by the decomposition products of electrolyte covers the cathode incessantly, which not only lead to inferior discharge capacity but also to a low and unstable coulombic efficiency, as shown in Fig. 4b.

The charge/discharge profiles of $\mathrm{Li} / \mathrm{LiNi}_{0.5} \mathrm{Mn}_{1.5} \mathrm{O}_{4}$ cells with and without FEC are given in Fig. $4 \mathrm{c}$ and Fig. 4d. It can be found that the potential difference between charge and discharge plateaus for the cell without FEC is much larger than that with FEC, suggesting severe polarization of $\mathrm{LiNi}_{0.5} \mathrm{Mn}_{1.5} \mathrm{O}_{4}$ electrode caused by the excessive SEI film growth. In the presence of FEC, the electrode polarization is greatly decreased due to the stable FEC derived SEI film. 

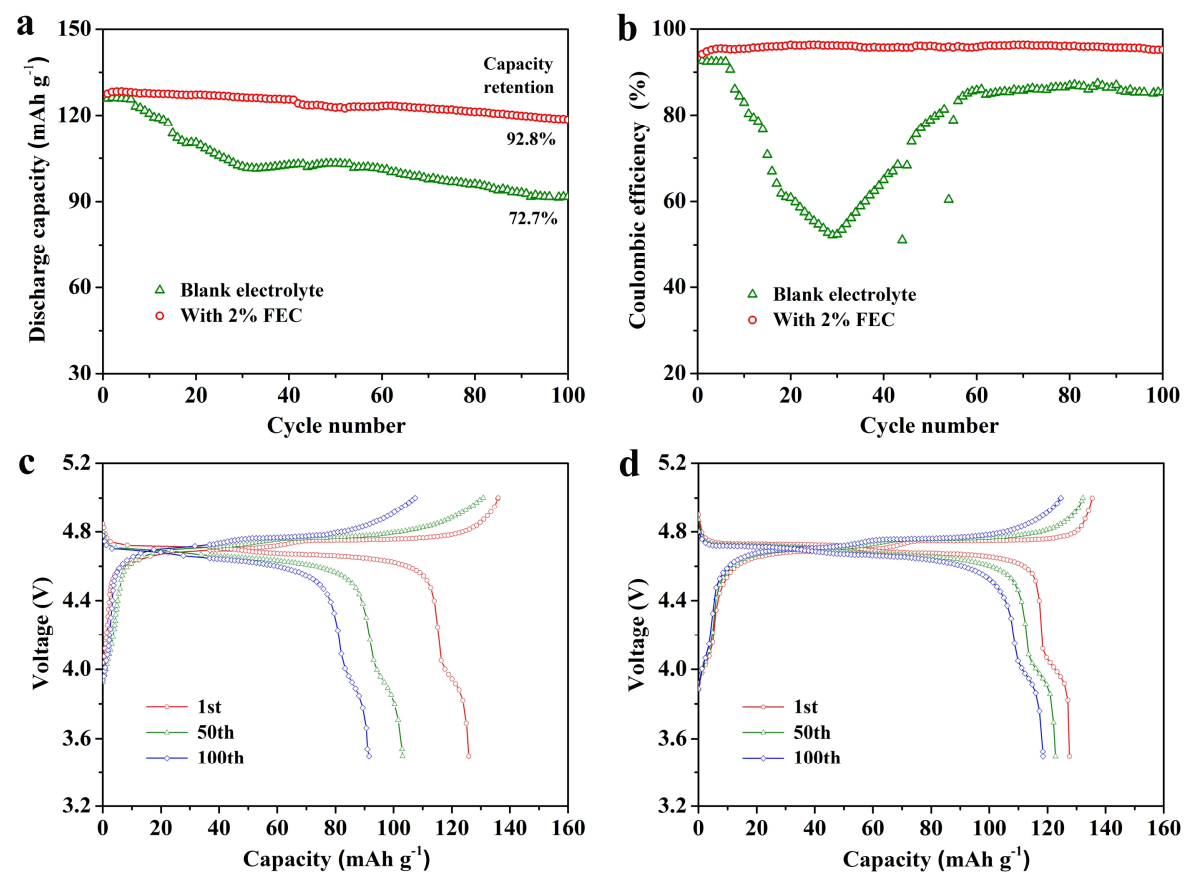

Fig. 4 Cycling performance of $\mathrm{Li} / \mathrm{LiNi}_{0.5} \mathrm{Mn}_{1.5} \mathrm{O}_{4}$ cells at $55^{\circ} \mathrm{C}$ : (a) discharge capacity retention, (b) coulombic efficiency, charge/discharge profiles of the cell (c) without FEC and (d) with FEC.

\section{Conclusion}

In this work, FEC was introduced to the electrolyte for improving the electrochemical performance of the high voltage $\mathrm{LiNi}_{0.5} \mathrm{Mn}_{1.5} \mathrm{O}_{4}$ cathode. Incorporation of $2 \%$ FEC improved the discharge capacity retention of $\mathrm{Li} / \mathrm{LiNi}_{0.5} \mathrm{Mn}_{1.5} \mathrm{O}_{4}$ cell form $82.7 \%$ to $92.3 \%$ after 200 cycles at room temperature, and from $72.7 \%$ to $92.8 \%$ after 100 cycles at $55{ }^{\circ} \mathrm{C}$. The EIS and chronoamperometry results revealed that FEC alleviates the electrolyte decomposition under high voltage and temperature conditions and forms a less resistive film on the cathode surface.

\section{Acknowledgement}

This work was financially supported by Scientific and Technological Research and Development Foundation of Shenzhen City (JCYJ20140418193546111), 973 National Defense Project (613142020201) and Shenzhen Key Laboratory of Functional Polymer Foundation (FP20140008).

\section{References}

[1] J.B. Goodenough, Acc. Chem. Res. 46 (2013) 1053-1061.

[2] A.W. Bhutto, A.A. Bazmi, G. Zahedi, J.J. Klemeš, Journal of Cleaner Production 71 (2014) 168-180.

[3] S. Tan, Y.J. Ji, Z.R. Zhang, Y. Yang, ChemPhysChem 15 (2014) 1956-1969.

[4] N.-S. Choi, J.-G. Han, S.-Y. Ha, I. Park, C.-K. Back, RSC Adv. 5 (2015) 2732-2748.

[5] L. Liao, P. Zuo, Y. Ma, Y. An, G. Yin, Y. Gao, Electrochim. Acta 74 (2012) 260-266.

[6] I.A. Profatilova, C. Stock, A. Schmitz, S. Passerini, M. Winter, J. Power Sources 222 (2013) 140-149.

[7] M.-H. Ryou, G.-B. Han, Y.M. Lee, J.-N. Lee, D.J. Lee, Y.O. Yoon, J.-K. Park, Electrochim. Acta 55 (2010) 2073-2077.

[8] Y. Park, S.H. Shin, H. Hwang, S.M. Lee, S.P. Kim, H.C. Choi, Y.M. Jung, J. Mol. Struct. 1069 (2014) 157-163.

[9] Y. Li, F. Lian, L. Ma, C. Liu, L. Yang, X. Sun, K. Chou, Electrochim. Acta 168 (2015) 261-270. 